\title{
Sublokatorstwo jako kategoria kultury polskiej
}

\author{
„O czymkolwiek Polska rozmawia - zmienia temat. [...] \\ Polska zna się na Polsce, ale nic o niej nie wie - \\ jest sercem tajemniczym, ciemnym. \\ Ale czym wypełniona? Jaka jej krew? \\ Kto by się dowiadywat, zostanie wygnany. \\ Objawi mu się wystawa światowa na Marsie [...]".
}

Piotr Matywiecki, Otwiera się z tomu Powietrze i czerń z 2009 roku

(Matywiecki, 2009, s. 635)

Teksty zebrane w drugim numerze „Studia Litteraria et Historica” opowiadają o prawach lokatorskich i sublokatorskich powinnościach. 0 gospodarzach i gościach. 0 normalsach i nosicielach piętna. O presji większości i jej recepcji przez mniejszość. Pokazują wzory kultury warunkujące postawy i praktyki społeczne, a zatem rozstrzygające o kształcie kultury - od relacji intymnych po przestrzeń publiczną. Sztuka i nauka nie tylko nie pozostają tutaj eksterytorialne, lecz są szczególnie narażone na uwikłanie w system poprzez odpowiednio: fantazmatyczną reprodukcję jego struktur i dostarczanie uzasadnień status quo.

Kłopoty sublokatorek/sublokatorów zazwyczaj zaczynają się, zanim jeszcze sformułują one/oni jakiekolwiek roszczenie. Wystarczy, że zaczną problematyzować swoją sytuację. Czynią bowiem wówczas widocznym to, co ma pozostawać niewidoczne i niewyartykułowane. Przekonała się o tym Sublokatorka z prozy Hanny Krall. Hanna Krall natomiast - nazywając zjawisko - dostarczyła nowej kategorii opisu, a więc także narzędzia analizy i krytyki kultury opartej na dominacji i podporządkowaniu.

Związane z nimi praktyki tak skutecznie pacyfikują zbiorową świadomość, że inne sposoby myślenia i postępowania wydają się w najlepszym razie marginalne i niezgodne z intuicją, w najgorszym zaś - szalone. Dominacja symboliczna zakłada pewien rodzaj wspólnictwa ze strony tych, którzy jej podlegają. Nie chodzi tu ani o bierne podporządkowanie, ani swobodny wybór. Posługując się tą paradoksalną ofertą „przymusowego wyboru", grupa dominująca narzuca instytucjom i aktorom społecznym dopuszczalną listę tematów - bez uciekania się do otwartej przemocy. Bystroniowskie „tematy, które mi odradzano” określa się na tej liście mianem „ideologicznych”.

Polska jest bastionem ideologicznego użytku ze słowa „ideologia”. Tymczasem - jak wiedzą ci, którym zdarzyło się czytać Karla Mannheima, Pierre’a Bourdieu czy Louisa Althussera - ideologia nie jest tylko „zestawem (fałszywych) idei, w które mniej lub bardziej chętnie wierzą podmioty historyczne. To raczej pole, w obrębie którego owym 
podmiotom przyznaje się tożsamość; ideologia łączy się nierozdzielnie z ich poczuciem tego, gdzie znajdują się w relacji z innymi w społeczeństwie, jak również w relacji wobec państwa i rodziny" (Spector, 2001, cyt. za: LaCapra, 2009, s. 16). Oddziaływanie ideologii jest najskuteczniejsze wówczas, gdy sama o sobie nie wie. Przemoc symboliczna maskuje wówczas nie tyle represyjność instytucji oficjalnie z represją kojarzonych, ale przede wszystkim samą siebie.

„Osobiście nigdy nie zetknąłem się z sublokatorstwem”... Sublokator idealny to taki, który zaprzecza własnemu statusowi sublokatora. Jego rolą jest poświadczać wyidealizowany autowizerunek lokatora. Sublokator dostarcza lokatorowi alibi w razie oskarżenia tego ostatniego o praktyki dyskryminacyjne. Szczególnie cenny jako panaceum na innych sublokatorów - takich, którzy nie upraszają o tolerancję, lecz żądają równouprawnienia. Z punktu widzenia lokatorów sublokatorzy dzielą się zatem na dobrych i złych. Niezależnie jednak od dobrego lub złego sprawowania, jednym i drugim można wymówić dach nad głową, czerpiąc z gotowej już palety racjonalizacji oraz sankcji moralnych, które oferuje kultura przemocy i wykluczenia.

Staramy się opisać społeczno-kulturową oczywistość, czyli niewidoczność tego, co na samym wierzchu i widoczne gołym okiem. Pytamy także o czynniki i warunki, które umożliwiałyby zmianę.

Elżbieta Janicka i Joanna Tokarska-Bakir

\section{Bibliografia}

LaCapra, D. (2009). Historia w okresie przejściowym. Doświadczenie, tożsamość, teoria krytyczna. (K. Bojarska, Tłum.). Kraków: Universitas.

Matywiecki, P. (2009). Otwiera się (z tomu Powietrze i czerń z 2009 r.). W P. Matywiecki, Zdarte okładki (19652009) (s. 635). Wrocław: Biuro Literackie.

Spector, S. (2001). Was the Third Reich Movie-Made? Interdisciplinarity and the Reframing of 'Ideology'. American Historical Review, 106, 460-484. 